To be published: Brittney Dawney and Joshua M. Pearce, "Optimizing the solar water disinfection (SODIS) method by decreasing turbidity with NaCl", Journal of Water, Sanitation and Hygiene for Development 2(2) pp, 87-94 (2012). doi: 10.2166/washdev.2012.043

\title{
Optimizing the Solar Water Disinfection (SODIS) Method by Decreasing Turbidity with $\mathrm{NaCl}$
}

\author{
Brittney Dawney ${ }^{1}$ and Joshua M. Pearce ${ }^{2}$ \\ 1. Department of Civil Engineering, Queen's University, Kingston, ON Canada \\ 2. Department of Materials Science \& Engineering and Department of Electrical \& \\ Computer Engineering, Michigan Technological University, Houghton, MI USA \\ * contact: pearce@mtu.edu
}

\begin{abstract}
.
Solar water disinfection (SODIS) has proven to be effective at reducing diarrheal incidence in epidemiological intervention studies. However, the SODIS method is limited to waters of low turbidity ( $<30 \mathrm{NTU})$. This study investigates the use of common table salt $(\mathrm{NaCl})$ to reduce the turbidity of water containing suspended colloidal clay particles for use in the SODIS method. Three representative clays found in tropical soils (kaolinite, illite, and bentonite) were tested at three levels of turbidity (50, 100, and 200 NTU) for their flocculating behaviour with multiple $\mathrm{NaCl}$ concentrations to find the optimum. Supernatants were tested for sodium concentration for comparison against health and taste thresholds. Results show that unlike kaolinite and illite, pure bentonite solutions were shown to be very responsive to $\mathrm{NaCl}$ and produced supernatants with as low as 4 NTU (98\% particle removal efficiency). This study has shown that $\mathrm{NaCl}$, in combination with high-activity clay particles in solution, may effectively reduce turbidity to levels suitable for SODIS treatment, thereby expanding the number of people who can utilize the technology effectively.
\end{abstract}

Keywords: clay, drinking water, flocculation, sanitation, SODIS, sodium, turbidity 
To be published: Brittney Dawney and Joshua M. Pearce, "Optimizing the solar water disinfection (SODIS) method by decreasing turbidity with NaCl", Journal of Water, Sanitation and Hygiene for Development 2(2) pp, 87-94 (2012). doi: 10.2166/washdev.2012.043

\section{Introduction}

The overwhelming number of people without adequate access to clean water for drinking and sanitation purposes calls for the provision of an appropriate method of treating microbiologically contaminated water (World Health Organization 2010). Solar water disinfection (SODIS) has been proven in both bench and field scale trials to significantly reduce microbial content in contaminated water, and associated incidence of diarrhea in users (Centre for Disease Control 2008; Graf et al. 2010; Meierhofer 2006; World Health Organization 2002). However, the technology is limited to relatively clear water (with turbidity less than 30 nephalometric turbidity units [NTU]); therefore, there is significant need to provide a practical method of reducing turbidity in water prior to solar disinfection.

This study investigates the use of a common reagent, table salt $(\mathrm{NaCl})$, in facilitating the settling of colloidal clay particles in water, with the aim of expanding the availability of the SODIS technology. First, the SODIS method is reviewed along with the effects of turbidity, colloidal particles and sodium content. Then, three representative clays found in tropical soils (kaolinite, illite, and bentonite [sodium form]) were tested at three levels of turbidity (50, 100, and $200 \mathrm{NTU}$ ) for their flocculating behaviour with five concentrations $(0.001 \mathrm{M}, 0.005 \mathrm{M}, 0.01 \mathrm{M}, 0.05 \mathrm{M}$, and $0.1 \mathrm{M})$ of $\mathrm{NaCl}$. The supernatant was tested for remaining sodium concentration for comparison against health and taste thresholds. The results are then reviewed, discussed and conclusions are drawn about the viability of $\mathrm{NaCl}$ in reducing turbidity in waters containing colloidal clay particles.

\section{Background}

\section{Solar Water Disinfection}

Although specialized methods are needed to appropriately purify chemical contamination of drinking water supplies in poor regions (Hashmi \& Pearce, 2011), one of the most technically simple, affordable, and practical systems for disinfecting microbiologicallycontaminated water is the solar water disinfection (SODIS) system (World Health Organization 2002). This system treats contaminated water by inactivating microorganisms through a synergistic combination of optical and thermal processes and requires only a transparent container (Meierhofer \& Wegelin 2002). As it employs pointof-use treatment, the clean water can be used and stored with a reduced risk of secondary contamination. Furthermore, at an annual cost of US\$0.40-US\$3.00, depending on location, it is an extremely low-cost water treatment method (Meierhofer \& Landolt 2008; World Health Organization 2002) and is one of the most inexpensive household treatments available (Clasen et al. 2007).

The inactivation of select bacteria, viruses, and protozoa due to UV-A radiation and heat has been studied extensively in studies under both simulated and natural conditions (Berney et al. 2006; Boyle et al. 2008; Dejung et al. 2007; Gómez-Couso 2009; Heaselgrave et al. 2006; Joyce et al. 1996; Méndez-Hermida 2007; McGuigan et al. 1998; Rijal \& Fujioka 2001). It has been shown that a synergistic effect in low-turbidity water 
To be published: Brittney Dawney and Joshua M. Pearce, "Optimizing the solar water disinfection (SODIS) method by decreasing turbidity with NaCl", Journal of Water, Sanitation and Hygiene for Development 2(2) pp, 87-94 (2012). doi: 10.2166/washdev.2012.043

is observed when water temperature exceeds $45^{\circ} \mathrm{C}$, at which point the combined inactivation effectiveness is greater than the individual contributions of radiation and heat (McGuigan et al. 1998). The effectiveness of the SODIS method at decreasing diarrheal incidence has also been investigated in epidemiological intervention studies and has proven to be credible: a decrease in diarrhea incidence by as much as $86 \%$ has been observed (Centre for Disease Control 2008; Graf et al. 2010; Meierhofer 2006; World Health Organization 2002). The method has shown to be particularly effective at reducing diarrhea in children under the age of five (Conroy et al. 1995; 1996; 1999; 2001; Graf et al. 2010; Rai et al. 2010; Rose et al. 2006).

\section{The Effect of Turbidity}

The World Health Organization has stated that treating turbid water is "a special concern", as turbidity particles shield the UV radiation that inactivates microbes in the water (World Health Organization 2002), which compromises the effectiveness of the SODIS treatment process. Numerous microbiological studies have revealed that highly turbid waters do not allow for the previously mentioned synergistic effect to occur (Gómez-Couso et al. 2009; Kehoe et al. 2001; McGuigan et al. 2008). Treatment of highly turbid waters is possible, but requires achieving temperatures of at least $55^{\circ} \mathrm{C}$ (Joyce et al. 1996). At such high temperatures and high turbidity, inactivation occurs by pasteurization; that is, by thermal mechanisms only: McGuigan et al. (2008) showed that in highly turbid water (200 NTU), 99\% inactivation of E. coli occurred only $1 \mathrm{~cm}$ into the optical path. There is therefore a significant need for a low-cost, practical method for reducing turbidity in source water prior to treatment by solar disinfection, which would allow for faster treatment.

\section{Suspended colloidal particles}

Relatively large and dense solid particles have settling velocities high enough such that they will settle in aqueous solution due to gravity. However, colloidal particles remain suspended due to their small size and (generally) electronegative surface charge. One method of inducing the settling of colloidal particles is through the process of coagulation-flocculation, by which colloids are destabilized and aggregated, ultimately resulting in their removal. The use of polyelectrolytes to facilitate coagulationflocculation has been studied and applied extensively, especially in the treatment of suspended particles in industrial water and wastewater treatment processes. Mainly the polyelectrolytes alum and ferric salts are used (Alaerts \& Van Haute 1983), due to their high valence charge, which facilitates adsorption onto the colloidal particle (Alaerts \& Van Haute 1981; Juo 2003). The use of coagulation-flocculation in water treatment in developing countries has been tested and proven to be effective; however, the availability of these chemicals and relatively high cost place this treatment method beyond the means of many people (World Health Organization 2002). The use of Moringa Oleifera has shown to be effective at reducing turbidity as well as improving microbial quality in water (Nkurunziza et al. 2009; Pritchard et al. 2009; Ferreira et al. 2011); however, it is 
To be published: Brittney Dawney and Joshua M. Pearce, "Optimizing the solar water disinfection (SODIS) method by decreasing turbidity with NaCl", Journal of Water, Sanitation and Hygiene for Development 2(2) pp, 87-94 (2012). doi: 10.2166/washdev.2012.043

not available in all regions of concern and the process requires extraction of the lectin from the seed.

\section{Sodium content}

For acclimatized adults, the physiological need for sodium is $184-230 \mathrm{mg} /$ day (Dahl 1972), attainable by consuming about $460-575 \mathrm{mg} /$ day of $\mathrm{NaCl}$. However, average daily sodium intake values vary across countries, age, and gender (Elliot \& Brown 2007). Tolerable limits and reference values vary similarly. For the purpose of this study, the tolerable upper limit of daily salt intake for North Americans of $5800 \mathrm{mg}$, corresponding to approximately $2400 \mathrm{mg}$ of sodium (Food and Nutrition Board, 2004), was used as a maximum allowable limit for a user's intake of sodium due to water treated with $\mathrm{NaCl}$. Based on data from North American men and women, it is recommended that the average healthy adult male consumes $3.7 \mathrm{~L}$ /day of water from all sources (food and drinking water), and women should consume on average $2.7 \mathrm{~L} /$ day (Food and Nutrition Board 2004). This implies that for a SODIS user consuming the North American average of 3.7 and $2.7 \mathrm{~L}$ /day of water treated with the proposed $\mathrm{NaCl}$ method, the sodium content must not exceed $650 \mathrm{mg} / \mathrm{L}$ for men and $890 \mathrm{mg} / \mathrm{L}$ for women, and should be as low as possible so as to allow intake of sodium through food. It should be acknowledged that SODIS users are likely to consume less drinking water and salt than the North American reference values. The taste threshold for $\mathrm{NaCl}$ in water is approximately $640 \mathrm{mg} / \mathrm{L}$ (Wiesenthal et al. 2007); therefore, concentrations in the supernatant should not exceed this value, which corresponds to approximately $256 \mathrm{mg} / \mathrm{L}$ of sodium

\section{Research goals}

This bench-top experiment investigates the effectiveness of a readily available electrolyte, sodium chloride $(\mathrm{NaCl})$ in reducing turbidity in waters due to colloidal clay particles. The flocculating behaviour of different types of clay in saline solutions has been documented (Akther et al. 2008; Gibbs 1983; 1985; Hsi \& Clifton, 1960; Panayiotopoulos et al. 2004). Furthermore, there is potential for the well-known flocculating behaviour of clays to apply to complex clay and mud combinations (Mietta et al. 2009). The effectiveness of $\mathrm{NaCl}$ at reducing turbidity due to colloidal clay particles in the context of household water treatment may significantly impact the availability of SODIS as a household water treatment option in developing countries.

\section{Methodology}

\section{Preparation of turbid samples}

The following types of clays were tested for their flocculating behaviour with $\mathrm{NaCl}$ : kaolinite, illite, and sodium bentonite, which naturally occur tropical soils (Gómez-Couso et al., 2009; Juo 2003). The preparation of the turbid samples followed that outlined by Gómez-Couso et al. (2009). Soil was added to $1000 \mathrm{ml}$ of distilled water to obtain 
To be published: Brittney Dawney and Joshua M. Pearce, "Optimizing the solar water disinfection (SODIS) method by decreasing turbidity with NaCl", Journal of Water, Sanitation and Hygiene for Development 2(2) pp, 87-94 (2012). doi: 10.2166/washdev.2012.043

turbidity levels of 50, 100, and 200 NTU, covering a wide range of possible field conditions as outlined by McGuigan et al. (1998).

\section{Concentrations of $\mathrm{NaCl}$}

Five different concentrations of $\mathrm{NaCl}$ were tested originally in order to find the range in which the optimal concentration exists. These concentrations were $0.001 \mathrm{M}, 0.005 \mathrm{M}$, $0.01 \mathrm{M}, 0.05 \mathrm{M}$, and $0.1 \mathrm{M}$, corresponding to $0.0584 \mathrm{~g}, 0.2922 \mathrm{~g}, 0.5844 \mathrm{~g}, 2.922 \mathrm{~g}$, and $5.844 \mathrm{~g}$ of $\mathrm{NaCl}$ per liter, respectively. Once the minimum concentration that produced a supernatant of <30 NTU was found, the range in which the optimal concentration lies was narrowed to between $0.5844 \mathrm{~g}$ and $2.922 \mathrm{~g}$. Further testing was then conducted to determine the optimal amount of $\mathrm{NaCl}$ using concentrations of $0.013 \mathrm{M}, 0.017 \mathrm{M}, 0.021$ $\mathrm{M}, 0.026 \mathrm{M}, 0.030 \mathrm{M}$, and $0.034 \mathrm{M}$, corresponding to $0.75 \mathrm{~g}, 1.00 \mathrm{~g}, 1.25 \mathrm{~g}, 1.50 \mathrm{~g}, 1.75$ $\mathrm{g}$, and $2.00 \mathrm{~g}$ of $\mathrm{NaCl}$ per liter of water.

\section{Coagulation-flocculation with $\mathrm{NaCl}$}

Standard jar test experiments were conducted to determine the flocculating behaviour of $\mathrm{NaCl}$ with each type of clay, as outlined in the ASTM Standard Practice for CoagulationFlocculation Jar Test of Water (D2305-08). Temperature was held constant at $21 \pm$ $0.5^{\circ} \mathrm{C}$. Samples were flash-mixed for a period of 1 minute at $130 \mathrm{rpm}$ and then underwent slow-mix at $15 \mathrm{rpm}$ for a period of 20 minutes. Samples were then allowed to settle for 60 minutes, and qualitative and quantitative observations were recorded at 15-minute increments. Turbidity was measured with a portable Orbeco turbidimeter and is expressed in NTU, following the procedure outlined in the ASTM Standard Test Method for Determination of Turbidity Above 1 Turbidity Unit (D7315-07a). pH was monitored with a Fisher Accumet $1003 \mathrm{~N}$ portable $\mathrm{pH}$ meter.

\section{Quantity of sodium ions present in supernatant}

$25 \mathrm{ml}$ of supernatant was collected at a depth of $60 \mathrm{~mm}$ and then heated to $90^{\circ} \mathrm{C}$ for 300 minutes with $2 \mathrm{ml}$ of $1.0 \mathrm{M} \mathrm{HNO}_{3}$ to ensure any solids were completely dissolved in the solution. Quantitative inductively coupled plasma by optical emission spectroscopy (ICPOES) analysis of the sodium ions present in the supernatant was then performed with a Varian Vista AX CCD Simultaneous ICP-AES.

The entire procedure was repeated for a second suite of trials.

\section{Results}

\section{Changes in turbidity}

$\mathrm{NaCl}$ in pure solutions of bentonite was found to be very effective and demonstrated as high as $98 \%$ removal efficiency as can be seen in Figure 1. For solutions of kaolinite and 
To be published: Brittney Dawney and Joshua M. Pearce, "Optimizing the solar water disinfection (SODIS) method by decreasing turbidity with NaCl", Journal of Water, Sanitation and Hygiene for Development 2(2) pp, 87-94 (2012). doi: 10.2166/washdev.2012.043

illite, $\mathrm{NaCl}$ was effective at reducing turbidity to below the 30 NTU SODIS threshold only when the initial turbidity was $50 \mathrm{NTU}$, corresponding to a maximum removal efficiency of $50 \%$. All data points shown are the average of three measurements with the turbidimeter, corresponding to a maximum error of $5.5 \%$.

Figure 1 illustrates the settling kinetics of pure bentonite suspensions for: a) 50 NTU, b) 100 NTU, and c) 200 NTU. The eye-guide horizontal line at 30 NTU is the SODIS limit and the concentrations of salt that exceed the allowable limit are marked with an asterisk.
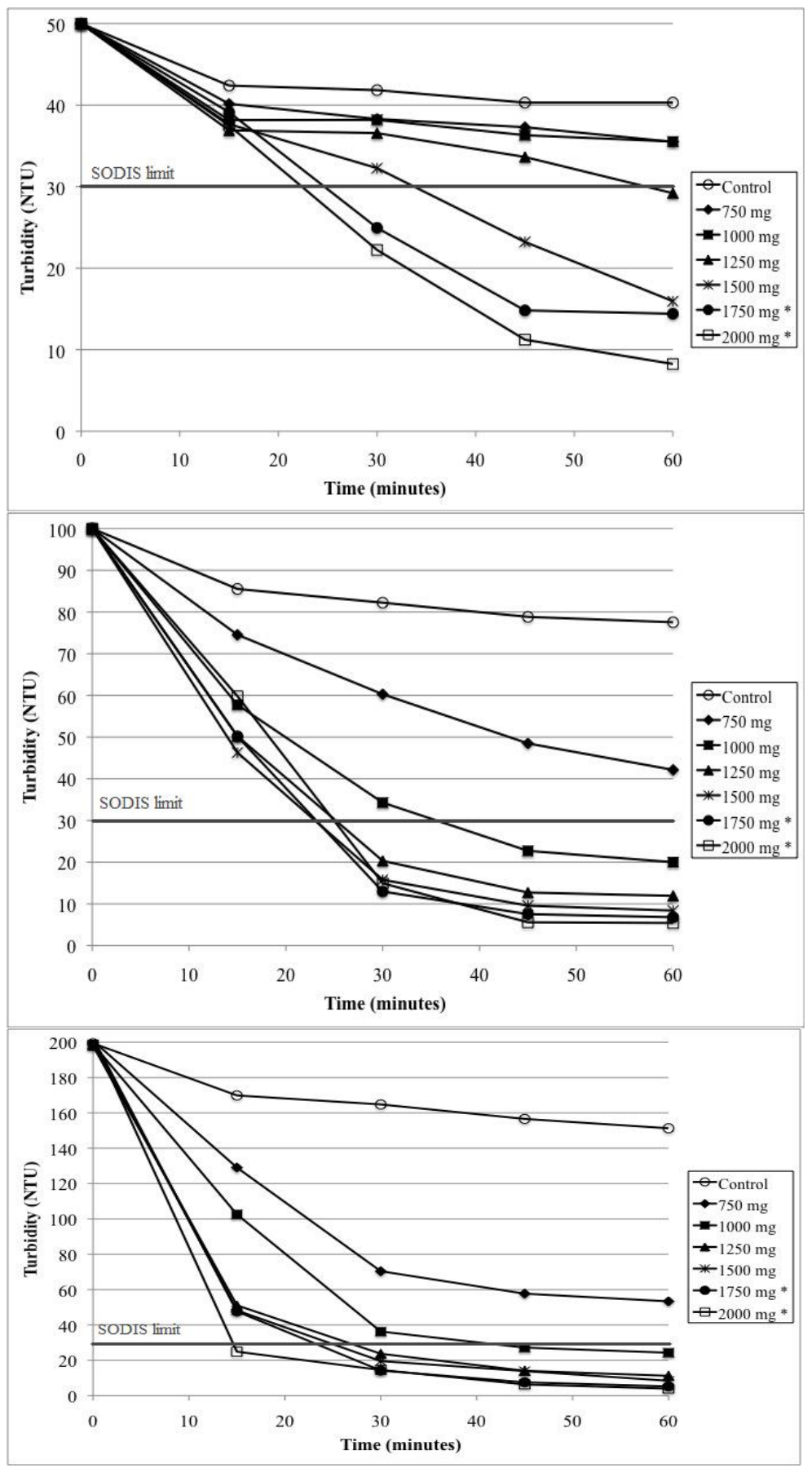
To be published: Brittney Dawney and Joshua M. Pearce, "Optimizing the solar water disinfection (SODIS) method by decreasing turbidity with NaCl", Journal of Water, Sanitation and Hygiene for Development 2(2) pp, 87-94 (2012). doi: 10.2166/washdev.2012.043

Figure 1. Settling kinetics of $100 \%$ bentonite suspensions from an initial turbidity of a) 50 NTU, b) 100 NTU, and c) 200 NTU. The concentrations marked with an asterisk resulted in supernatants with a sodium concentration that exceeds allowable limits.

\section{Changes in $\mathrm{pH}$}

For varying initial turbidity levels, initial $\mathrm{pH}$ ranged from 6.3 to 8.1 for bentonite solutions, 5.1 to 5.8 for illite solutions, and 5.2 to 5.8 for kaolinite solutions, reflecting the natural alkalinity and acidity of these types of clays. Overall it was found that $\mathrm{pH}$ varied at most by 0.4 over the course of settling, decreasing slightly for solutions of bentonite and increasing slightly for solutions of kaolinite and illite.

\section{Sodium concentration in supernatant}

Figure 2 illustrates the concentration of sodium remaining in the supernatant of suspensions that settled below the SODIS threshold of $30 \mathrm{NTU}$ in 60 minutes.

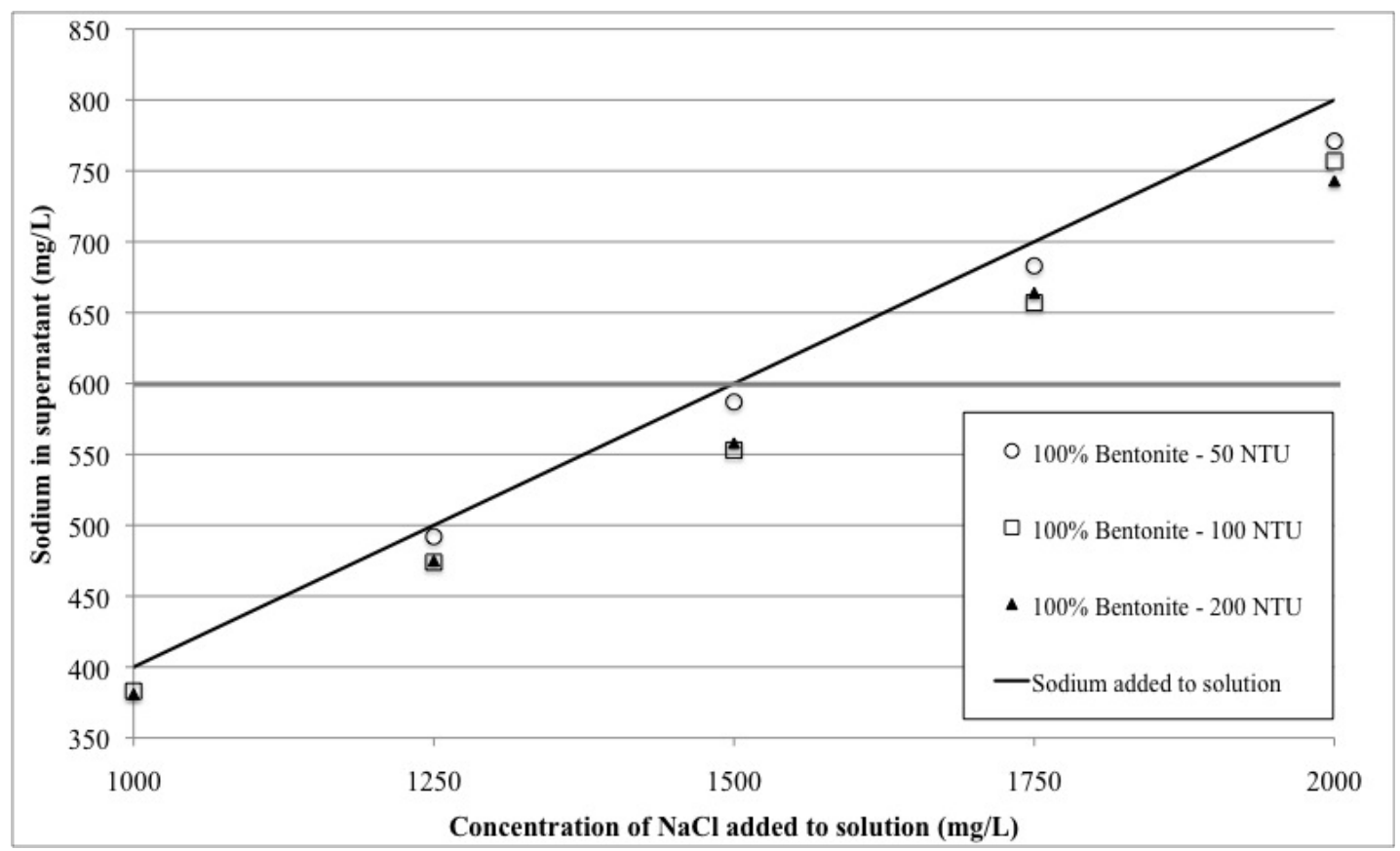

Figure 2. Sodium content remaining in supernatant after 60 minutes of settling with a final turbidity of less than 30 NTU.

As shown in Figure 2, ideal results tend toward the lower left-hand quadrant. The solid horizontal line denotes the maximum health limit based on an intake of $2400 \mathrm{mg}$ of sodium per day.

\section{Discussion}


To be published: Brittney Dawney and Joshua M. Pearce, "Optimizing the solar water disinfection (SODIS) method by decreasing turbidity with NaCl", Journal of Water, Sanitation and Hygiene for Development 2(2) pp, 87-94 (2012). doi: 10.2166/washdev.2012.043

\section{Effectiveness of $\mathrm{NaCl}$ at reducing turbidity}

The results show that $\mathrm{NaCl}$ can be used to effectively reduce turbidity in water containing colloidal particles of high-activity clays such as sodium bentonite. This is because when $\mathrm{NaCl}$ is added to a suspension of sodium bentonite particles, the accumulation of sodium ions decreases the thickness of the electric double layer and reduces the hydration of the clay particles, causing flocculation (Roscoe Moss Company 1990). Kaolinite and illite were not as responsive to the addition of $\mathrm{NaCl}$ in the solution due to their relatively low cation exchange capacity (CEC) and mineral structure. Turbid source water containing these types of colloidal particles is likely not suitable for treatment with $\mathrm{NaCl}$.

For pure bentonite with an initial turbidity of $50 \mathrm{NTU}, 1250 \mathrm{mg} / \mathrm{L}$ of $\mathrm{NaCl}$ was required to facilitate settling to below the SODIS threshold. However, only $1000 \mathrm{mg} / \mathrm{L}$ of $\mathrm{NaCl}$ was required for suspensions with an initial turbidity of 100 and 200 NTU. Furthermore, greater percent reductions in turbidity were observed for samples with a relatively high initial turbidity, consistent with flocculation-coagulation mechanisms and the "jumpstart" effect that has been applied in industrial wastewater treatment, in which bentonite is added to turbid solutions to more efficiently facilitate flocculation (Yang et al. 2007). The results also suggest that water with an initial turbidity greater than 200 NTU may possibly be treated with these concentrations of $\mathrm{NaCl}$ with desirable results.

\section{Sodium content}

Though a range of $\mathrm{NaCl}$ concentrations produced supernatant turbidities below the SODIS threshold of 30 NTU, only those that satisfy health and taste limits may be considered as suitable for subsequent use as drinking water. As shown in Figure 2, a maximum concentration of $1500 \mathrm{mg} / \mathrm{L}$ of $\mathrm{NaCl}$ could be used without exceeding the allowable limit of $600 \mathrm{mg} / \mathrm{L}$ of sodium in the supernatant; therefore, only those solutions in which a maximum of $1500 \mathrm{mg} / \mathrm{L}$ of $\mathrm{NaCl}$ was added may be considered for drinking water use. While none of the supernatants contained sodium below the taste threshold of $256 \mathrm{mg} / \mathrm{L}$, several fell below the sodium content in Gatorade ( 460 mg/L), which suggests that certain solutions may be suitable for drinking water. Even if certain samples of water treated with the current method may not be suitable for drinking purposes, all of them may potentially be used for sanitation and hygiene purposes following SODIS treatment.

\section{Implications of study}

The results of the current study show that $\mathrm{NaCl}$ may be an effective means of reducing turbidity in water caused by naturally occurring high-activity colloidal clay particles. The results also suggest that $\mathrm{NaCl}$, in combination with high-activity clay, may be used to treat turbid water according to the jumpstart effect utilized in industrial water treatment. Both implications may appreciably broaden the scope of people with access to SODIS as a household water treatment. 
To be published: Brittney Dawney and Joshua M. Pearce, "Optimizing the solar water disinfection (SODIS) method by decreasing turbidity with NaCl", Journal of Water, Sanitation and Hygiene for Development 2(2) pp, 87-94 (2012). doi: 10.2166/washdev.2012.043

\section{Future studies}

It is recommended that the flocculating behaviour of $\mathrm{NaCl}$ with suspensions of calcium bentonite and magnesium bentonite be explored. Following these bench tests, field studies should be conducted in areas dominated by high-activity clays to determine if the results of bench tests are reproducible at the field scale and in relatively uncontrolled conditions. Studies should be conducted to explore the use of bentonite additives in combination with $\mathrm{NaCl}$ to produce a small-scale jumpstart effect. Optimization of this technology should be explored by determining the influence of controlled $\mathrm{pH}$ on settling. Furthermore, literature shows that bentonite has been used in the removal of contaminants in Sudan (Madsen \& Schlundt 1989). Thus future work is needed to investigate the effectiveness of bentonite and $\mathrm{NaCl}$ combinations in removing microbiological contaminants. If the current method is deemed suitable for use in the field, a detailed cost analysis and life cycle analysis should be performed for comparison against other treatments. Further work must be done to explore and identify all possible health risks associated with this type of technology if the treated water is to be used for drinking purposes, particularly as they relate to sodium intake in various populations.

\section{Conclusions}

With appropriate social programming, SODIS has proven to be effective at reducing diarrheal incidence associated with microbiologically contaminated water in developing communities around the world. However, its synergistic mechanisms are limited to relatively clear water of less than 30 NTU; therefore, a simple and appropriate method of reducing turbidity prior to SODIS treatment may significantly expand the number of users with access to SODIS. This study has shown that $\mathrm{NaCl}$, in combination with highactivity clay particles in solution, may effectively reduce turbidity to levels suitable for SODIS treatment. This may appreciably increase the number of people who can practice SODIS as a means of accessing clean water for sanitation purposes, and with some improvement, for drinking purposes. Future work should address the viability of this technology with different types of bentonite and at the field scale, as well as the effectiveness of bentonite and $\mathrm{NaCl}$ combinations at reducing microbiological content in water.

\section{References}

Akther, S., Hwang, J. \& Lee, H. Sedimentation characteristics of two commercial bentonites in aqueous suspensions. Clay Miner. 43, 449-457 (2008).

Alaerts, G. \& Van Haute, A. Stability of colloid types and optimal dosing in water flocculation. Studies in Environmental Science 19, 13-29 (1981).

Berney, M., Weilenmann, H., Simonetti, A. \& Egli, T. Efficacy of solar disinfection of Escherichia coli, Shigella flexneri, Salmonella Typhimurium and Vibrio cholerae. Journal of Applied Microbiology 101, 828-836 (2006). 
To be published: Brittney Dawney and Joshua M. Pearce, "Optimizing the solar water disinfection (SODIS) method by decreasing turbidity with NaCl", Journal of Water, Sanitation and Hygiene for Development 2(2) pp, 87-94 (2012). doi: 10.2166/washdev.2012.043

Bessho, K. \& Degueldre, C. Generation and sedimentation of colloidal bentonite particles in water. Applied Clay Science 43, 253-259 (2009).

Centers for Disease Control and Prevention Household water treatment options in developing countries: solar water disinfection. (2008). Available at

<http://www.cdc.gov/safewater/publications_pages/options-sodis.pdf>

Clasen, T., Schmidt, W.P., Rabie, T., Roberts, I. \& Cairncross, S. Interventions to improve water quality for preventing diarrhoea: systematic review and meta-analysis. BMJ 334, 782-782 (2007).

Clasen, T., Cairncross, S., Haller, L., Bartram, J. \& Walker, D. Cost-effectiveness of water quality interventions for preventing diarrhoeal disease in developing countries. Journal of Water and Health 5, 599 (2007).

Conroy, R.M., Elmore-Meegan, M., Joyce, T., McGuigan, K.G. \& Barnes, J. Solar disinfection of drinking water and diarrhoea in Maasai children: a controlled field trial. Lancet 348, 1695-1697 (1996).

Conroy, R.M., Meegan, M.E., Joyce, T., McGuigan, K. \& Barnes, J. Solar disinfection of drinking water protects against cholera in children under 6 years of age. Archives of Disease in Childhood 85, 293-295 (2001).

Conroy, R.M., Meegan, M.E., Joyce, T., McGuigan, K. \& Barnes, J. Solar disinfection of water reduces diarrhoeal disease: an update. Archives of Disease in Childhood 81, 337-338 (1999).

Dahl, L.K. Salt and hypertension. American Journal of Clinical Nutrition 25, 231-244 (1972).

Dejung, S., Wegelin, M., Fuentes, I., Almanza, G., Jarro, R., Navarro, L., Arias, G., Urquieta, E., Torrico, A., Fenandez, W., Iriarte, M., Birrer, C., \& Stahel, W. Effect of solar water disinfection (SODIS) on model microorganisms under improved and field SODIS conditions. Journal of Water Supply: Research and Technology—AQUA 56, 245 (2007).

Elliot, P. \& Brown, I. Sodium Intakes Around the World - Background document prepared for the Forum and Technical Meeting on Reducing Salt Intake in Populations (Paris 5-7th October 2006). World Health Organization (2007).

Ferreira, R.S., Napoleao, T.H., Santos, A.F.S., Sa, R.A., Carneiro-da-Cunha, M.G., Morais, M.M.C., Silva-Lucca, R.A., Oliva, M.L.V., Coelho, L.C.B.B., Paiva, P.M.G. Coagulant and antibacterial activities of the water-soluble seed lectin from Moringa oleifera. Letters in Applied Microbiology 53, 186-192 (2011).

Food and Nutrition Board Dietary Reference Intakes: Water, Potassium, Sodium, Chloride, and Sulfate. (The National Academy Press: Washington, D.C., 2004)

Gibbs, R.J. Coagulation rates of clay minerals and natural sediments. SEPM Journal of Sedimentary Research 53, (1983). 
To be published: Brittney Dawney and Joshua M. Pearce, "Optimizing the solar water disinfection (SODIS) method by decreasing turbidity with NaCl", Journal of Water, Sanitation and Hygiene for Development 2(2) pp, 87-94 (2012). doi: 10.2166/washdev.2012.043

Gibbs, R.J. Settling velocity, diameter, and density for flocs of illite, kaolinite, and montmorillonite. SEPM Journal of Sedimentary Research 55, (1985).

Gómez-Couso, H., Fontan-Sainz, M., McGuigan, K.G. \& Ares-Mazas, E. Effect of radiation intensity, water turbidity and exposure time on the survival of Cryptosporidium during simulated solar disinfection of drinking water. Acta Tropica 112, 43-48 (2009).

Gómez-Couso, H., Fontán-Saínz, M., Sichel, C., Fernández-Ibáñez, P. \& Ares-Mazás, E. Efficacy of the solar water disinfection method in turbid waters experimentally contaminated with Cryptosporidium parvum oocysts under real field conditions. Tropical Medicine and International Health 14, 620-627 (2009).

Graf, J., Zebaze Togouet, S., Kemka, N., Niyitegeka, D., Meierhofer, R., \& Gangoue Pieboji, J. Health gains from solar water disinfection (SODIS): evaluation of a water quality intervention in Yaoundé, Cameroon. Journal of Water and Health 8, 779-796 (2010).

Hashmi, F. \& Pearce, J.M. Viability of Small-Scale Arsenic-Contaminated Water Purification Technologies for Sustainable Development in Pakistan. Sustainable Development 19(4), 223-234 (2011).

Hsi, H. \& Clifton, D.F. Flocculation of selected clays by various electrolytes. Clays and Clay Minerals 9, 269-275 (1960).

Joyce, T., McGuigan, K., Elmo, M. \& Conroy, R. Inactivation of fecal bacteria in drinking water by solar heating. Applied and Environmental Microbiology 62, 399-402 (1996).

Juo, A. Tropical soils : properties and management for sustainable agriculture. (Oxford University Press: New York N.Y., 2003).

Madsen, M. \& Schlundt, J. Low technology water purification by bentonite clay flocculation as performed in Sudanese villages: bacteriological examinations. Water Research 23, 873-882 (1989).

McGuigan, K., Joyce, T., Conroy, R., Gillespie, J. \& Elmore-Meegan, M. Solar disinfection of drinking water contained in transparent plastic bottles : characterizing the bacterial inactivation process. Journal of Applied Microbiology 84, 1138-1148 (1998).

Meierhofer, R. \& Landolt, G. Factors supporting the sustained use of solar water disinfection Experiences from a global promotion and dissemination programme. Desalination 248, 144-151 (2009).

Meierhofer, R. \& Wegelin, M. Solar water disinfection: A guide for the application of SODIS. (2002).at <http://www.sodis.ch/methode/anwendung/ausbildungsmaterial/index_EN>

Mietta, F., Chassagne, C., Manning, A.J. \& Winterwerp, J.C. Influence of shear rate, organic matter content, $\mathrm{pH}$ and salinity on mud flocculation. Ocean Dynamics 59, 751-763 (2009). 
To be published: Brittney Dawney and Joshua M. Pearce, "Optimizing the solar water disinfection (SODIS) method by decreasing turbidity with NaCl", Journal of Water, Sanitation and Hygiene for Development 2(2) pp, 87-94 (2012). doi: 10.2166/washdev.2012.043

Nkurunziza, T., Nduwayezu, J.B., Banadda, E.N. \& Nhapi, I. The effect of turbidity levels and Moringa oleifera concentration on the effectiveness of coagulation in water treatment. Water Sci. Technol. 59, 1551-1558 (2009).

Panayiotopoulos, K.P., Barbayiannis, N. \& Papatolios, K. Influence of Electrolyte Concentration, Sodium Adsorption Ratio, and Mechanical Disturbance on Dispersed Clay Particle Size and Critical Flocculation Concentration in Alfisols. Communications in Soil Science and Plant Analysis 35, 1415-1434 (2004).

Pritchard, M., Mkandawire, T., Edmondson, A., O’Neill, J.G. \& Kululanga, G. Potential of using plant extracts for purification of shallow well water in Malawi. Physics and Chemistry of the Earth, Parts A/B/C 34, 799-805 (2009).

Rebhun, M., Narkis, N. \& Wachs, A. Effect of polyelectrolytes in conjunction with bentonitic clay on contaminants removal from secondary effluents. Water Research 3, 345-355 (1969).

Rijal, G.K. \& Fujioka, R.S. Synergistic effect of solar radiation and solar heating to disinfect drinking water sources. Water Science and Technology 43, 155-162 (2001).

Rose, A., Roy, S., Abraham, V., Holmgren, G., George, K., Balraj, V., Abraham, S., Muliyil, J., Joseph, A., \& Kang, G. Solar disinfection of water for diarrhoeal prevention in southern India. Archives of Disease in Childhood 91, 139-141 (2006).

Sobsey, M. Managing Water in the Home: Accelerated Health Gains from Improved Water Supply. (Department of Protection of the Human Environment, World Health Organization. WHO/SDE/WSH/02.07: 2002).

Wiesenthal, K.E., McGuire, M.J. \& Suffet, I.H. Characteristics of salt taste and free chlorine or chloramine in drinking water. Water Science and Technology 55, 293-300 (2007).

Yang, Y., Zhou, T., Qiao, Q. \& Chen, S. Experimental Study of Wastewater Treatment of Reactive Dye by Phys-Chemistry Method. Journal of China University of Mining and Technology 17, 96-100 (2007). 